\title{
Retention and Dissemination of Arrest Records: Judicial Response
}

On August 10, 1965, Dale Menard was taken into custody by the Los Angeles Police Department on a charge of burglary. ${ }^{1}$ He was held two days without a hearing and then released, the police being satisfied that "there [was] no ground for making a criminal complaint against the person arrested." 2 Under a California statute the arrest was classified as "detention only." However, the record of his arrest, including fingerprints, had been forwarded to the Federal Bureau of Investigation, which incorporated it into criminal identification files. ${ }^{3}$ Menard filed a complaint in the District Court for the District of Columbia alleging that he was arrested without probable cause and seeking to compel the Attorney General of the United States and the Director of the FBI to remove his fingerprints and accompanying notation from the Bureau's files. The court granted summary judgment for the defendants. The Court of Appeals for the District of Columbia Circuit reversed in an opinion by Judge Bazelon stating that the FBI's authority to retain and disseminate Menard's record was not without limit. The court nevertheless remanded the case for trial, declaring that the issues presented required a more complete factual development before a final decision could be reached. ${ }^{4}$

Full resolution of the legal issues presented by Menard $v$. Mitchell could have a substantial impact on the present system of criminal justice in the United States. The practice of taking fingerprints, photographs, and other identification data of every person arrested by local, state, and federal law enforcement officers and disseminating that data at their discretion prior to final disposition of the case is well

1 Menard v. Mitchell, 430 F.2d 486, 488 n.I (D.C. Cir. 1970).

2 Id. at 488.

3 Id. at 487 .

$4 I d$. at 494 . On remand, the District Court for the District of Columbia held that the FBI's authority to disseminate arrest records outside the federal government was limited to distribution to law enforcement agencies for law enforcement purposes. The action for expungement could not, however, be maintained until administrative remedies were exhausted, and then Menard's first resort would be in the state courts. 39 U.S.L.W. 2725 (D.D.G. June 15, 1971). 
established. ${ }^{5}$ In fact, the collection ${ }^{6}$ and immediate transmission ${ }^{7}$ of data to state and federal law enforcement agencies are often required by statute. Even in the absence of statutory mandate, these procedures are usually held to be well within the authority of police. ${ }^{8}$ After a dis-

5 The number of people affected by this practice is staggering. Although the total number of individuals arrested in the United States is unknown, the FBI reported, on the basis of returns representing $71 \%$ of the population, that in 1969 a total of 5,773,988

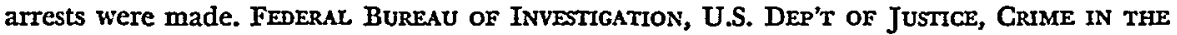
UNITED STATES: UNIFORM CRIME REPORTS-1969, at 107-08 (1969). One study has estimated that "about 40 percent of the male children living in the United States today will be arrested for a nontraffic offense sometime in their lives." PRESIDENT'S COMM'N ON LAW Enforcenient \& Administration of Justice, Report: The Challenge of Crime in a FreE SocIETy 247 (1967). The statistics do not reveal how many people arrested are not convicted; however, the FBI reports may show a rough trend. Data covering a population exceeding 66 million showed that in 1969 , of $2,402,979$ persons charged, $15.9 \%$ or 382,074 were acquitted or had charges dismissed and $18.5 \%$ or 444,551 were referred to juvenile courts. FEderal BuREAU of INvestigation, U.S. DeP'T OF Justice, supra, at 102. Many more individuals would be included in the arrested but not convicted category if figures existed for those, like Menard, who were arrested but not formally charged.

- Local law enforcement officials are often under a statutory duty to take fingerprints, photographs, and other identification information of all persons arrested for felonies, persons reasonably suspected to be fugitives, "well known and habitual criminals," and persons arrested for certain specified misdemeanors. See, e.g., FLA. Stat. ANN. § 30.31 (1969); ILI. Rev. STat. ANN. ch. 38, § 206-2 (1970); IND. ANN. Stat. § 47-857 (1970).

Some courts have extended the scope of statutory authorization to collection of identification data on all arrested persons, holding that statutory authority to maintain records, at police discretion, of persons arrested for certain offenses implies the authority to maintain records of all arrests, unless the statute specifically prohibits record keeping in certain instances. See, e.g., United States v. Laub Baking Co., 283 F. Supp. 217 (N.D. Ohio 1968); Poyer v. Boustead, 3 III. App. 2d 562, 122 N.E.2d 838 (1954).

7 See, e.g., Der. Code AnN. tit. 11, § 8511 (1968); Fla. Stat. ANn. \$ 30.31(2) (1969); InL. Rev. Stat. ch. 38, § 206-3 (1970); IND. ANN. Stat. § 47-859 (1965); Wis. Stat. ANN. $\S 165.84$ (1970).

8 United States v. Laub Baking Co., 283 F. Supp. 217 (N.D. Ohio 1968); United States v. Krapf, 180 F. Supp. 886 (D.N.J. 1960), aff'd, 285 F.2d 647 (3d Cir. 1961); United States v. Kelly, 55 F.2d 67 (2d Cir. 1932); Shannon v. State, 207 Ark. 658, 182 S.W.2d 384 (1944); Owensby v. Morris, 79 S.W.2d 934 (Tex. Civ. App. 1985). See also Annot., 83 A.L.R. 127 (1933). The fifth amendment privilege against self-incrimination does not prohibit these practices. United States v. Laub Baking Co., supra; Gilbert v. United States, 366 F.2d 923 (9th Cir. 1966). If the arrest is lawful, the fourth amendment will not bar fingerprints and photographs taken after arrest as evidence for trial. United States v. Laub Baking Co., supra. The courts further hold that the invasion of privacy involved in taking the fingerprints, photographs, and the making of the record is justified. See, e.g., Kolb v. O'Connor, 14 III. App. 2d 81, 142 N.E.2d 818 (1957).

Furthermore, dissemination of data before disposition of the case is usually upheld. See Poyer v. Boustead, 3 Ill. App. 2d 562, 122 N.E.2d 838 (1954); Voelker v. Tynđall, 226 Ind. 43, 75 N.E.2d 548 (1947); McGovern v. Van Riper, 140 N.J. Eq. 341, 54 A.2d 469 (Ch. 1947); Hansson v. Harris, 252 S.W.2d 600 (Tex. Civ. App. 1952). Many states also authorize local police to establish, with the cooperation of the state identification bureau, their own identification files in which data may be maintained. See, e.g., Del. Code ANN. tit. I1, § 8514(1) (1968); IND. ANN. STAT. § 47-858 (1970).

Some courts declare that the taking and dissemination of arrest data before disposition is justified because no stigma attaches to fingerprinting and photographing since the pro- 
position of the case is reached ${ }^{9}$ the arrest data, often with notation of subsequent processing of the individual through the criminal justice system, are retained in local, state, and federal criminal identification files or computer data banks..$^{10}$ If the arrest did not lead to a conviction, the information retained constitutes what is called the "arrest record."11 Although these records are often declared confidential, they are widely

cedures are primarily for identification purposes. See, e.g., Sterling v. Oakland, 208 Cal. App. 2d 1, 24 Cal. Rptr. 696 (1962); Poyer v. Boustead, 3 Ill. App. 2d 562, 122 N.E.2d 838 (1954). Moreover, data may be required in some cases even without arrest or criminal charge. See Thom v. New York Stock Exch., 306 F. Supp. 1002 (S.D.N.Y. 1969) (fingerprinting required for employees of stock exchange firms); Norman v. Gity of Las Vegas, 64 Nev. 38, 177 P.2d 442 (1947) (fingerprinting required for liquor store employees).

These procedures are also held to be necessary as a practical matter to facilitate the performance of law enforcement functions such as investigation and prosecution. See, e.g., United States v. Kelly, 55 F.2d 67 (2d Gir. 1932); United States v. Laub Baking Co., 283 F. Supp. 217 (N.D. Ohio 1968); Downs v. Swann, 111 Md. 53 (1909); Barletta v. McFeeley, 107 N.J. Eq. 141, 152 A. 17 (Ch. 1930), affd, 109 N.J. Eq. 241, 156 A. 658 (Ct. Err. \& App. 1931), aff'd, 113 N.J. Eq. 67, 166 A. 144 (Ct. Err. \& App. 1933).

For a survey of the law relating to the authority to take and retain fingerprints, see A. Moenssens, Fingerprints and the LAW 39-72, 85-107 (1969).

9 The term "disposition" will be used to signify some terminal point in the prosecution of a case, such as acquittal, dismissal, charges dropped, no charges brought, or investigation discontinued.

10 For examples indicating the rapid move toward the computexization of arrest files, see NEw York State IDentification \& INTElligence SYstem, System DevelopMent Plan (1967); California Crime Technological Research Foundation, Project Search: StanDARDiZfD Data Elements for CRIMinal History Files (1970). Some of the computerization projects are making their first attempts to deal with the problems presented by these records. See, e.g., id.

11 "Arrest record" is a term describing nonconviction arrest data retained after disposition. It is important to make several distinctions between the arrest record and other information that is also stored. While facts surrounding a current arrest are technically part of the record, they should for three reasons be subject to separate consideration by the courts. First, until a final disposition is reached obviously it is impossible to tell whether the arrest record is actually an arrest record. Second and more important, the public has a right to know the basic facts surrounding the arrest in order to prevent secret arrests and to ensure public supervision of the police. Morrow v. District of Columbia, 417 F.2d 728, 741-42 (D.C. Cir. 1969). Third, any dissemination or publication of present arrest facts, as long as they are true, is probably constitutionally privileged. See, e.g., Time v. Hill, 385 U.S. 374 (1967).

Another part of criminal identification files is current investigative data, which are and should be restricted in order to protect current police investigations and informants. See note 63 infra. After an investigation has terminated without arrest, however, such data retained in files should be subject to the same considerations as are discussed below concerning arrest records.

Finally, where there is a conviction, the record becomes a true criminal record. Because use of such records does not involve harm to an innocent or potentially innocent person, they are beyond the scope of the present analysis. For an excellent discussion of the problems raised by conviction records, see Gough, The Expungement of Adjudication Records of Juvenile and Adult Offenders: A Problem of Status, 1966 WASH. U.L.Q. 147. See also National Council on Crime \& Delinquency, Annulment of a Conviction of Crime: A Model Act, 8 Crome \& DenINQ. 97 (1962). 
disseminated and used without restriction both within and without the criminal justice system. ${ }^{12}$ To anyone desiring to determine the extent of a person's past involvement with law enforcement authorities, the arrest record is extremely important: it is the only way to obtain this information efficiently and inexpensively through identification of the person by name alone. ${ }^{13}$

Widespread use of the arrest record, however, can inflict definite and demonstrable harms on the arrested individual. Inside the criminal justice system, he may be subjected to unfair treatment by police, prosecutors, and courts; ${ }^{14}$ outside the system, he may suffer damage to his reputation and to his economic and psychological well-being. ${ }^{15}$ It is questionable whether any such consequences should be permitted to occur to a person who has not been judged guilty but who is presumed innocent. Until recently, most courts have neglected the problem; in the absence of legislative action they have left decisions concerning the retention, dissemination, and use of these records entirely to police discretion. ${ }^{16}$ But there is a current effort to reexamine the problem with a view toward eliminating some of the adverse consequences of arrest records. On one level, some state legislatures have enacted statutes providing for return or expungement of a record when certain criteria are met. ${ }^{17}$ Unfortunately, these statutes exist only in a few states. Furthermore, they are limited in effect, they have varying criteria for expungement, they usually do not apply to local identification bureaus, they seldom contain provisions for return of records disseminated beyond these bureaus, they rarely contain enforcement provisions, and they do not apply to the FBI, the largest collector of arrest records. In the absence of expungement statutes a few courts, as in Menard, have recognized the need to restrict the scope of the police

12 See, e.g., A. Miller, Assault on Privacy 34-35 (1971); Committee to Investigate the EFFects of Police ArRest Records on UNEMployment in the District of Colvumis, RePORT 9 (1967) [hereinafter cited as DUNCAN REPORT]; Karst, "The Files": Legal Controls Over the Accuracy and Accessibility of Stored Personal Data, 31 LAw \& ConTEMP. Pros. 342, 365-66 (1966).

13 But see text at note 126 infra.

14 See text and notes at notes $24-31$ infra.

15 See text and notes at notes 76-81 infra.

16 See text and notes 20 \& 70 infra.

17 Expungement statutes as of 1966 are listed and analyzed in detail in Gough, supra note 11, at 162-68, 174-78. Since 1966 several states have added their own acts. See, e.g., Ir.. Rev. Stat. ANN. ch. 38, § 206.5 (1970). See generally Baum, Wiping Out a Criminal or Juvenile Record, 40 CALIF. ST. B.J. 816 (1965); Booth, The Expungement Myth, 38 L.A. BAR BuLx. 161 (1963); Comment, Criminal Records of Arrest and Conviction: Expungement from the General Public Access, 3 CAL. WEst. L. REv. 121 (1967); Comment, Guilt by Record, 1 CAL. WEST L. REv. 126 (1965). The term "expungement," it should be noted, is really a misnomer; most of the statutes cited provide for return or sealing of records rather than their destruction. 
discretion in light of the debilitating effects on the individual resulting from the widespread use of his arrest record. This comment will analyze the judicial response to the problems raised by (1) retention and use of adult ${ }^{18}$ nonconviction arrest records within the criminal justice system, and (2) dissemination of these records at police discretion outside the system. In addition, it will offer suggestions, focusing primarily on the common law, ${ }^{19}$ for the further development of judicial responsibility in this area.

\section{Retention and Use of Arrest Records Within the Criminal Justice System}

\section{A. Retention: the "Usefulness" Doctrine}

Most courts have been extremely hesitant to interfere with police discretion. In the absence of legislative action, they declare that all arrest records can be retained and exchanged freely within the criminal justice system. ${ }^{20}$ However, specific reasons for this position are rarely articulated. ${ }^{21}$ The proposition generally adopted is that retention of arrest records is justified by their potential future usefulness in helping police prevent crimes and apprehend criminals. ${ }^{22}$

18 The problems raised by juvenile records are equally significant. See, e.g., In re Smith, 310 N.Y.S.2d 617 (Family Ct. 1970). See generally PrEsidenT's Comm'N on LAW ENForcement \&. Administration of Justice supra note 5, at 44, 74 (1967). However, because of the special status of juvenile records, they should be the subject of separate consideration and are not included specifically in this analysis. See Gough, supra note 11, at 168-78. See also S. Rubin, Crime ANd Juvenile Delinguency, 145-63 (1961).

19 Many of the issues presented may have a constitutional dimension. Thus far, however, there has been no specific judicial discussion of any of the possible constitutional issues. But see notes 46, 50, 110, \& 129 infra.

20 Herschel v. Dyra, 365 F.2d 17 (7th Cir.), cert. denied, 385 U.S. 973 (1966); Sterling v. Oakland, 208 Cal. App. 2d 1, 24 Cal. Rptr. 696 (1962); Walker v. Lamb, 254 A.2d 265, (Del. Ch.), aff'd, 259 A.2d 663 (Super. Ct. Del. 1969); Purdy v. Mulkey, 228 So. $2 d 132$ (Dist. Ct. App. Fla. 1969); People v. Lewerenz, 42 Ill. App. 2d 410, 192 N.E.2d 401 (1963); Kolb v. O'Connor, 14 Ill. App. 2d 81, 142 N.E.2d 818 (1957); Voelker v. Tyndall, 226 Ind. 43, 75 N.E.2d 548 (1947); State ex rel. Mavity v. Tyndall, 224 Ind. 364, 66 N.E.2d 755 (1946), cert. denied, 333 U.S. 834, rehearing denied, 333 U.S. 858 (1948); Coppock v. Reed, 189 Iowa, 581, 178 N.W. 382 (1920); Miller v. Gillespie, 196 Mich. 423, 163 N.W. 22 (1917); Fernicola v. Keenan, 136 N.J. Eq. 9, 39 A.2d 851 (Ch. 1944); Statman v. Kelly, 47 Misc. 2d 294, 262 N.Y.S.2d 799 (Sup. Ct. 1965); Weisberg v. Police Dep't, 46 Misc. 2d 846, 260 N.Y.S. $2 \mathrm{~d} 554$ (Sup. Ct. 1965). See also Village of Homewood v. Dauber, 85 IIl. App. 2d 127, 229 N.E.2d 304 (1967); In re Molineux, 177 N.Y. 395, 69 N.E. 727 (1904); People ex rel. Joyce v. New York, 27 Misc. 658, 59 N.Y.S. 418 (Sup. Ct. 1899); Hansson v. Harris, 252 S.W.2d 600 (Tex. Civ. App. 1952); Hodgeman v. Olsen, 86 Wash. 615, 150 P. 1122 (1915). Cf. Note, 27 Temple L.Q. 441 (1954).

21 One court did explain that retention was necessary in order to furnish superior police officials with definite and authoritative data concerning the activities of the department. Miller v. Gillespie, 196 Mich. 423, 163 N.W. 22 (1917). However, after disposition of the case, purely statistical data should be sufficient for this purpose.

22 See, e.g., Purdy v. Mulkey, 228 So. 2d 132 (Dist. Ct. App. Fla. 1969); Fernicola v. Keenan, 136 N.J. Eq. 9, 39 A.2d 851 (Ch. 1944). 
Practical considerations support this broad rationale in most cases. ${ }^{23}$ Neutral identification information contained in the records, such as fingerprints and photographs, can be quite helpful to local police if the individual is ever under investigation again. Positive identification is often essential to link a suspect to a crime or to protect a person who is innocent. Also, imputational information such as the arrest notation can indicate a pattern of conduct that may be the basis for a future arrest or for a decision to press charges. If a rearrest is made, the arrest record may furnish facts concerning prior conduct which, although not sufficient to warrant conviction in the previous case, may still be useful to trained interpreters of records.

Presently, law enforcement officers utilize the record in subjecting the individual to rearrest on the basis of past arrests ${ }^{24}$ and in deciding whether to bring formal charges. ${ }^{25}$ Prosecutors consider past arrests in determining the category of offense to be charged and in deciding whether to plea bargain. ${ }^{26}$ Courts use the record in denying release prior to trial or appeal, ${ }^{27}$ in setting bail, ${ }^{28}$ in determining whether a defendant's testimony is impeached by prior convictions, ${ }^{29}$ and in sentencing. ${ }^{30}$ Parole boards evaluate the record in deciding whether to grant parole. $^{31}$

While each of these law enforcement uses may be questioned, police, prosecutors, and courts in every jurisdiction have an equal need for this data. Free interchange of arrest records facilitates these functions. Although injury to innocent persons may result from retention and use of the records, this risk is outweighed in most cases by society's interest in the performance of these activities to protect the general public.

\section{B. Retention or Return: A Reexamination}

1. Retention of an Arrest Record Without Probable Cause. The Menard court did not decide whether further retention and use of the

23 It should be noted that usefulness of arrest records remains unproven since the closed system maintained by police impairs the ability to document usefulness. Therefore, only potential uses are considered here.

24 W. LA FAVE, ARrEst 287-88 (1965).

25 Id. at 141.

26 See D. Newman, Conviction: The Determination of Guilt or Innocence Wrthout

TRIAL 116 (1966) (lack of a "criminal record" often a reason for charge reduction).

27 See, e.g., Russell v. United States, 402 F.2d 185, 186 (D.C. Cir. 1968); Rhodes v. United States, 275 F.2d 78, 81-82 (4th Cir. 1960).

28 Russell v. United States, 402 F.2d 185, 186 (D.C. Cir. 1968).

29 See, e.g., Suggs v. United States, 407 F.2d 1272, 1275 (D.C. Cir. 1969); cf. Gordon v. United States, 383 F.2d 936 (D.C. Cir. 1967).

30 See, e.g., Powell v. State, 94 Okla. Crim. 1, 229 P.2d 230 (1951); Murphy v. State, 184

Md. 70, 40 A.2d 239 (1944).

31 See Duncan REPORT, supra note 12 , at 16. 
arrest record within the criminal justice system would be justified if Menard actually were arrested without probable cause. ${ }^{32}$ An examination of the nature of a record of arrest without probable cause in light of the common law rationale for retention of arrest records may suggest an answer.

The core of the arrest record is the notation of arrest. This notation either memorializes the arresting officer's perception connecting the arrested person with a particular crime or signifies a connection based upon a warrant. For the arrest to be legal, the connection with the crime must be reasonable or the warrant must be based on probable cause. $^{33}$ The arrest notation thus becomes the basis for a continuing inference by law enforcement officials that there were reasonable grounds at the time of the arrest for associating the arrested person with the crime. When an arrest is made without probable cause, however, the arresting officer's perception is by definition unreasonable and the continuing inference based on his perception is invalid; the arrest notation thus will not be useful. Furthermore, retention may unjustifiably injure the individual by subjecting him to law enforcement decisions based on the misleading record. ${ }^{34}$ To require the notation to be completed or changed to "detention only" would not eliminate these possibilities since even a police user might overlook such a qualification or regard it as a mere formality.

Of course, such neutral identification data as fingerprints and photographs are still accurate and will be at least as useful as the same data of a person who has never been arrested. However, when they are stored and used in conjunction with the misleading arrest notation, these data lose their neutrality and the same unjustified consequences flow from their use. To prevent these results, the courts could either require that the arrest notation be removed and that the neutral identification information be kept in completely separate files, or order 'return of all records relating to the unjustified arrest. If the first alternative were administratively infeasible, return of the entire arrest record would be warranted. ${ }^{35}$

2. Retention in Other Cases. The above analysis applies not only to an arrest made without probable cause, but also to several other

32 As Judge Bazelon pointed out, in Menard probable cause was not demonstrated. 430 F.2d at 492 n.28. There, the plaintiff had challenged the FBI's statutory authority to retain his record as a "criminal record." $I \dot{d}$. at 489 . Although the court dismissed this claim, the FBI's statutory authority should be interpreted on the basis of the common law purpose for retaining arrest records, as is discussed below.

33 LaFave; supra note 24, at 17-82.

34 Contra, Sterling v. Oakland, 208 Cal. App. 2d 1, 24 Cal. Rptr. 696 (1962).

35 See Wheeler v. Goodman, 298 F. Supp. 985 (W.D.N.C. 1969). But of. Herschel v. Dyra, 365 F.2d 17 (7th Cir.), cert. denied, 385 U.S. 973 (1966). 
situations. If an arrest is made with probable cause and it is later discovered that the arrest was based on mistaken identity or that no crime had occurred,,$^{36}$ the validity of the inference based on the arrest notation is destroyed. For the same reason applicable to an arrest without probable cause, retention is unjustified and return is warranted. ${ }^{37}$

On the other hand, this analysis does not apply directly to harassment arrest cases. In such cases the arrest is usually made with probable cause and nothing happens later to vitiate the continuing inference; the arrest record satisfies the usefulness criterion. Nevertheless, the motivation for a harassment arrest is unlawful and unrelated to the grounds for the arrest. The equitable notion of placing the individual who has been subject to abuse of police authority in status quo ante outweighs any usefulness that might result from retaining the records, and return is warranted. ${ }^{38}$ Indeed, in light of the willingness of the criminal justice system to let a potential criminal go unprosecuted as a means of deterring this type of police abuse, retention of arrest records in harassment cases would be anomalous.

Finally, it might be thought that a disposition of acquittal, dismissal, charges dropped, or no charges brought would itself be sufficient to justify return. If the law were consistent with the presumption of innocence, no disabilities would be permitted to occur without conviction and all records of arrests not resulting in conviction would be destroyed. With few exceptions, ${ }^{30}$ however, the only effect the courts have given the presumption of innocence is as a burden of proof..$^{40}$ Moreover, these dispositions do not necessarily controvert the usefulness of the record. Acquittal means only that the defendant was not proven guilty beyond a reasonable doubt. Other dispositions can result from the death of an only witness, prosecutorial discretion, or the illegal seizure of evidence. Because of these considerations, the simple fact that a person has not been found guilty should not be sufficient to compel return of the record. If, however, an individual can show that the potential harm to him outweighs the usefulness of the record to the criminal justice system, he should be able to require return. ${ }^{41}$ Otherwise, this decision should be left to police discretion.

36 This also may have been the case in Menard. $430 \mathrm{~F} .2 \mathrm{~d}$ at 488.

37 United States v. Jones, Crim. No. 36388-69 (D.C. Ct. Gen. Sess., April, 1970) (return required of all records after dismissal because of mistaken identity).

38 Several courts have required return in harassment arrest cases for this very reason. United States v. McLeod, 385 F.2d 734 (5th Cir. 1967); Wheeler v. Goodman, 298 F. Supp. 985 (W.D.N.C. 1969); Hughes v. Rizzo, 282 F. Supp. 881 (E.D. Pa. 1968).

30 See, e.g., Gow v. Bingham, 57 Misc. 66, 107 N.Y.S. 1011 (Sup. Ct. 1907).

40 See, e.g., State v. Edwards, 269 Minn. 343, 130 N.W.2d 623 (1964).

41 If data were available, it might be possible to use the "future usefulness" analysis to decide whether arrest records for certain types of crimes, such as disorderly conduct, 
Even when the record should be retained, Menard raises the subsidiary question of whether law enforcement officials are under a duty to complete the record. ${ }^{42}$ Because of the possibility of misinterpretation resulting in unjustifiable injury, retention of the record should be permitted only if the arrest notation and any subsequent notations of the processing of the individual through the criminal justice system-especially the final disposition-were both complete and accurate. ${ }^{43}$

\section{Legal Foundation for Requiring Return}

Several legal theories may compel the return of arrest records that are not useful to police. In Menard, Judge Bazelon suggested that if an arrest is without probable cause, it is doubtful whether the Constitution can tolerate "any adverse use of that information." 44 Indeed, one might argue that because the arrest was in violation of the fourth amendment, all "fruits" of that arrest should be eliminated. ${ }^{45}$ While this argument is compelling, the courts have hesitated to extend the application of the fourth amendment beyond the exclusion from trial of illegally seized evidence. ${ }^{46}$

Although most courts have not yet accepted the principle that retention and use of arrest records constitutes a common law invasion of privacy, ${ }^{47}$ this right, when examined in the context of the previous

should be returned after disposition. Statistics might prove that notation of certain crimes serves little or no usefulness in crime prevention. The probability of adverse consequences could be weighed against future usefulness of neutral identification data in deciding whether retention after disposition is justified. Without empirical data, however, discretion to maintain records must remain with the police.

42 Menard v. Mitchell, 430 F.2d 486, 492 (D.C. Cir. 1970).

43 For an excellent discussion of the problem of accuracy of records in general, see Karst, supra note 12, at 353-59.

44 Menard v. Mitchell, 430 F.2d 486, 491 (D.C. Cir. 1970). See also Case Comment, 46 NOTRE DAME LAW. 825 (1971).

46 See Silverthorne Lumber Co. v. United States, 251 U.S. 385 (1920); Smith v. United States, 344 F.2d 545 (D.C. Cir. 1965).

46 In Menard, Judge Bazelon cited Davis v. Mississippi, 394 U.S. 721 (1969), for the proposition that the Constitution might not tolerate "any adverse use" of the arrest record. 430 F.2d at 491 . The Supreme Court in Davis intimated that although fingerprints taken pursuant to an arrest without probable cause are inadmissible in a state court trial, detention for fingerprinting may under certain circumstances comply with the fourth amendment even without probable cause in the traditional sense. 394 U.S. at 727. Applying fourth amendment considerations to use of the entire record would present a different case because use of the misleading arrest notation would be involved. However, Davis appears to suggest that there may be limits to the Supreme Court's willingness to extend the fourth amendment.

47 See cases cited note 20 supra. See also Annot., 30 A.L.R.3d 203, 276 (1970). In rejecting invasion of privacy contentions in these cases, the courts have concluded that any invasion of privacy involved in retaining and using records is outweighed by the interest of society in having the police perform these functions. See, e.g., Kolb v. O'Connor, $14 \mathrm{III}$. App. 2d 81, 91, 142 N.E.2d 818, 824 (1957), in which the court held that Chicago police 
analysis, affords a basis for requiring return in all cases discussed above. An unreasonable intrusion into an individual's private affairs is commonly considered to be an invasion of his right of privacy. ${ }^{48}$ When an arrest without probable cause occurs, the initial intrusion is unreasonable. Retention and use of the arrest record would seem to be a part of that initial unreasonable intrusion and therefore unjustified. In cases of mistaken identity, on the other hand, the initial intrusion is reasonable. Discovery of the fact of mistaken identity, however, indicates that retention can serve no valid purpose and would constitute a new intrusion into private affairs.

Several problems still remain regarding a return requirement based on the right of privacy. While the right is widely held to exist at common law, it is not recognized in several states. ${ }^{49}$ In some instances it has been found to be either an implied constitutional right or a natural law right incorporated into the Constitution. The actual application of the constitutional right of privacy, however, has been limited to special situations, such as intrusion into an individual's intimate marital life. ${ }^{50}$ Finally, the types of actions that constitute an invasion of privacy are the subject of great debate. ${ }^{51}$ In many cases privacy aphad the right to retain the plaintiffs' records after acquittal or dropping of charges, declaring that "[ $[\mathrm{t}$ he rights of the individual must be subordinate to the safety of the public." See also Purdy v. Mulkey, 228 S.2d 132 (Fla. Dist. Ct. App. 1969); village of Homewood v. Dauber, 85 Ill. App. 2d 127, 229 N.E.2d 304 (1967); People v. Lewerenz, 42 Ill. App. 2d 410, 192 N.E.2d 401 (1963); Voelker v. Tyndall, 226 Ind. 43, 75 N.E.2d 548 (1947). But see United States v. Kalish, 271 F. Supp. 968 (D.P.R. 1967) (return of record required on privacy grounds after unsuccessful assertion of a constitutional right).

48 The concept of privacy was early recognized in Warren \& Brandeis, The Right to Privacy, 4 HARv. L. REv. 193 (1890). Since its publication the right has grown far beyond the authors' original conceptions. Prosser has organized the actions presently constituting invasion of privacy into four categories: (1) intrusion into the plaintiff's private affairs, (2) public disclosure of embarrassing private facts about the plaintiff, (3) publicity which places the plaintiff in a false light in the public eye, and (4) appropriation for defendant's advantage of plaintiff's name or likeness. Prosser, Privacy, 48 CaLIF. L. REv. 383 (1960).

49 See Prosser, supra note 48, at 388.

so In Griswold v. Connecticut, 381 U.S. 479 (1965), the Supreme Court held that a Connecticut statute forbidding use of contraceptives violates the marital right of privacy, which falls within the penumbra of the first, third, fourth, fifth, and ninth amendments. The case has given rise to much speculation about the scope of the constitutional right of privacy. See Comment, Privacy after Griswold-Constitutional or Natural Law Right? 60 Nw. U.L. REv. 813 (1966); cf. Lankford v. Gelston, 364 F.2d 197 (4th Cir. 1966). In United States v. Laub Baking Co., 283 F. Supp. 217 (N.D. Ohio 1968), in which the defendants in a federal criminal antitrust prosecution moved for a protective order relieving them from being photographed and fingerprinted by a federal marshal, the court, limiting Griswold to marital privacy, rejected the theory that a constitutional right is violated by the taking or retention of such records. Cf. Note, Discrimination on the Basis of Arrest Records, 56 CoRNELL L. REv. 470 (1971).

51 One commentator insists that privacy is not easily categorized and, indeed, that it is virtually impossible to describe the component parts of the tort. Kalven, Privacy in 
pears to be no more than a label determined by a balancing process in which a variety of personal interests are weighed against the need of society or of other individuals to intrude on those interests. ${ }^{52}$ Nevertheless, the magnitude of the individual's interests would seem to justify application of this right here.

Even if the privacy rationale were not adopted, return might be obtained in the cases previously discussed on the grounds that retention is outside police authority and that the individual has substantial interests that need protection. ${ }^{53}$ The traditional equity powers of a civil court in a new proceeding, or of a criminal court upon disposition of the case before it, ${ }^{54}$ should be sufficient to protect the individual from the threat of unjustified injury which would result from use of a record and to place him in status quo ante. Several arrest records have actually been ordered returned on this basis. ${ }^{55}$

\section{Effects of Requiring Return in These Cases}

Return of a record of an arrest made without probable cause or of a record in which the continuing inference is for some other reason invalid prohibits all further use of that record in law enforcement decisions. The return of only those records which are inherently.misleading might be preferable to the return or sealing of all records, as provided in expungement statutes, since records of valid arrests may still be useful to police. ${ }^{58}$ Another advantage over expungement statutes is that return could be required from all criminal identification bureaus.

Some of the problems inherent in expungement statutes also plague a common law solution. ${ }^{67}$ First, placing the burden on the individual

Tort Law-Were Warren and Brandeis Wrong? 31 LAW \& CONTEMP. Prob. 326 (1966). See generally S. Hofstadter \& G. Horowitz, The Right of Privacy (1964); A. Westin, PrIVACY AND Freedom (1967); Beaney, The Right to Privacy and American Law, 31 LAw \& GonTEMr. Prob. 253 (1966); Bloustein, Privacy as an Aspect of Human Dignity: An Answer to Dean Prosser, 39 N.Y.U.L. REv. 962 (1964).

52 See note 47 supra.

53 In a case like Menard, if the plaintiff can prove an immediate threat of irreparable injury due to retention of his arrest record, he may have standing to assert that his record should be returned simply because retention is action outside the scope of law enforcement agencies' statutory or common law authority. The Administrative Procedure Act, 5 U.S.C. § 702 (Supp. II, 1967), it has been argued, confers standing on individuals for judicial review of agency action, except as by law committed to agency discretion, which adversely affects them in fact. Davis, The Liberalized Law of Standing, 37 U. CHI. L. REv. 450 (1970). See also 3 K.C. Davis, Administrative LAW Treatise $\S 22.01$, at 210 (1965, Supp. 1970).

54 See Morrow v. District of Columbia, 417 F.2d 728 (D.C. Gir. 1969).

65 See cases cited notes 37 \& 38 sicpra.

56 But see text at notes $60 \& 125$ infra.

or For a discussion of the difficulties faced in expungement statutes, see articles cited note 17 supra. 
to initiate action functionally hampers his ability to vindicate his rights. Second, return is dependent on judicial action; an administrative remedy would be more efficient and less expensive. Third, the ability of police accurately to dispose of a matter by a complete record is sacrificed when the record is returned..$^{58}$ Fourth, although the return of a record from local files provides a partial remedy by precluding continued reference to that record, future use is not eliminated unless duplicate records sent to other law enforcement bureaus are also returned. Since copies of the record are forwarded to individuals and agencies throughout the nation, it is often impossible to identify everyone who has a copy. Moreover, it is difficult for a court to obtain jurisdiction over an outside law enforcement agency known to have a copy. ${ }^{59}$ A partial solution to this problem might be to include a provision in the injunctive order requiring the original disseminating party to be responsible for return of records sent outside the jurisdiction. Although proving continued retention in violation of the order would be difficult, the individual might be able to enforce compliance by initiating either a civil contempt proceeding or an action in tort for damages.60

A final point that must be made is that minimization of unfairness to those whose records are retained is entirely dependent on limiting the scope of dissemination and the range of use outside the criminal justice system. If this proves administratively impractical, the balancing of usefulness against harm to the individual will have to be recalculated.

\section{Dissemination of Arrest Records Outside the Criminal Justice System}

For the large majority of individuals whose arrest records are retained and for whom continuing inferences concerning the arrest are valid, difficult problems largely unresolved by the courts still exist. As dissemination of arrest records expands beyond the criminal justice system, the number of people who have access to records, the uses that are made of them, and their consequent adverse effects on individuals multiply dramatically. Before determining whether police discretion in this area should be limited, however, the present legal status of access to and dissemination of arrest records should be examined.

58 Return of records should be favored over their destruction because the individual will have the record if some matter arises later for which it is needed.

59 See, e.g., Walker v. Lamb, 254 A.2d 265 (Del. Ch.), aff'd, 259 A.2d 663 (Del. Super. Ct. 1969), in which the plaintiff requested an order requiring local police to obtain and return all copies of an arrest record they had sent to the FBI; cf. Roesch v. Ferber, 45 N.J. Super. 149, 131 A.2d 807, rev'd on other grounds, 48 N.J. Super. 281, 137 A.2d 61 (1957).

60 See text and notes at notes 117-121 infra, discussing similar enforcement remedies. 


\section{A. The Present Practice}

Public record statutes and information acts generally provide that records whose retention is required by law shall be open to reasonable public inspection. ${ }^{61}$ However, police investigative files compiled and preserved for law enforcement purposes are usually excluded. ${ }^{62}$ Even where statutes do not specifically exempt police records, courts have held such records confidential to protect current police investigations and persons submitting information to police. ${ }^{.3}$ Arrest records are included under this public policy umbrella of confidentiality. ${ }^{64}$

Classification of arrest records as confidential means in practice that although arrest records are not subject to public inspection, police can disseminate the records to virtually anyone at their discretion..$^{65} \mathrm{Dis}$ semination of FBI records is allowed by statute to "authorized officials," ${ }^{6}$ but a regulation of the Attorney General sets forth a rather broad list of authorized recipients, including governmental agencies in general, railroad police, insurance companies, and most banks. ${ }^{67}$

61 See, e.g., 5 U.S.C.A. § 552 (1967); Colo. Rev. STAT. ANN. § 113-2-1 (1963); IND. ANN. STAT. § 57-601 (Supp. 1970); N.J. REv. Star. § 47:1A-2 (Supp. 1971). See generally H. Cross, The PEOPLE'S RuGht to KNow (1953).

62 See, e.g., 5 U.S.C.A. § 552(b)(7) (1967); CAR. Gov't Code § 625-4(f); ConN. GeN. Stat. ANN. § 1-19 (Supp. 1971); WYo. STAT. ANN. § 9-692.3(b)(i) (Supp. 1969).

63 See United States v. Mackey, 36 F.R.D. 431 (D.D.C.), aff'd, 351 F.2d 794 (D.C. Cir. 1965); People v. Pearson, 111 Cal. App. 2d 9, 244 P.2d 35 (1952); Runyan v. Board of Prison Terms \& Paroles, 26 Cal. App. 2d 183, 79 P.2d 101 (1938); Lee v. Beach Publishing Co. 127 Fla. 600, 173 So. 440 (1937); State v. Mattio, 212 La. 283, 31 So. 2d 801, cert. denied, 332 U.S. 818 (1947); State v. Dallao, 187 La. 391, 175 So. 4 (1937); Whittle v. Munshower, 221 Md. 258, 155 A.2d 670 (1959); Hale v. City of New York, 251 App. Div. 826, 296 N.Y.S. 443 (1937); Public Serv. Mut. Ins. Co. v. Nassau County Fire Marshal, 55 Misc. 2d 951, 287 N.Y.S.2d 104 (Sup. Ct. 1967); People v. Carro, 199 N.Y.S.2d 365 (Oneida County Ct. 1960). But see Holcombe v. State ex rel. Chandler, 240 Ala. 590, 200 So. 739 (1941); Scott v. County of Nassau, 23 Misc. 2d 648, 252 N.Y.S.2d 135 (Sup. Ct. 1964); In re Story, 159 Ohio St. 144, 111 N.E.2d 385 (1953); Beckon v. Emery, 36 Wis. 2d 510, 153 N.W.2d 501 (1967); State ex rel. Youmans v. Owens, 32 Wis. 2d 11, 144 N.W.2d 793 (1966). See also Cross, supra note 61, at 95-121.

64 Whittle v. Munshower, 221 Md. 258, 155 A.2d 670 (1959); cf. United States v. Mackey, 36 F.R.D. 431 (D.D.C.), aff'd, 351 F.2d 794 (D.C. Cir. 1965); Lee v. Beach Publishing Co. 127 Fla. 600, 173 So. 440 (1937). See also Del. Code ANN. tit. 11, \& 88513 (1968); ILL. Rev. Stat. ANN. ch. 38, § 206-3 (Supp. 1970); ME. Rev. Stat. ANN. tit. 25, § 1631 (1964); Md. COde ANN. art. 88B, § 10 (1957); ORE. Rev. Stat. § 181.540 (Supp. 1970); VA. Code ANN. $\S 19.2$ (1960); Wash. Rev. Code ANN. § 72.50.140 (Supp. 1970).

65 See notes 12 supra \& 79 infra.

6628 U.S.C. \& 534(a)(2) (Supp. IV, 1969).

6728 C.F.R. § 0.85(b) (1970). Compare United States v. Kelly 55 F.2d 67 (2d Cir. 1932), the leading case authorizing federal agents to take fingerprints, in which the court declared, "It should be added that all United States attorneys and marshals are instructed by the Attorney General not to make public photographs, Bertillon measurements or fingerprints prior to trial, except when the prisoner becomes a fugitive from justice, and are required to destroy or to surrender to the defendant all such records after acquittal or when the prisoner is finally discharged without conviction. There is therefore as care- 
Several state statutes explicitly authorize dissemination to all governmental agencies. ${ }^{68}$ Although some statutes attempt to limit dissemination by state agencies, ${ }^{69}$ most do not and none apply to local police or the FBI.

Courts usually refuse to interfere with the police practice of limiting public access to arrest records but circulating the records at their discretion. ${ }^{0}$ Yet the rationale for this practice-to protect police investigations-obviously should not apply to arrest records after the investigation has terminated.71 Although no other reason has been given for the present practice, it might be explained by two other considerations: (1) police should not be exposed to excessive demands for information, and (2) records include certain investigative data access to which should be restricted but separation of which would be administratively impractical. The first reason appears trivial because even where records are public the inquirer must show a specific interest in the records..$^{72}$ Moreover, police are already under an obligation to furnish other similar information. ${ }^{73}$ The second reason may have some practical significance, but it should not be controlling as a matter of law, especially since some courts hold storage of secret information together with records to be no bar to public inspection. ${ }^{74}$ The present practice of uncontrolled police discretion should, therefore, be rejected;

ful provision as may be made to prevent the misuse of the records and there is no charge of any threatened improper use in the present case" (Emphasis added.) In Menard, the District Court for the District of Columbia has on remand severely restricted the scope of this regulation. See note 4 supra.

68 Idaho Code Ann. § 19-4807 (Supp. 1969); Kan. Gen. Stat. Ann. § 75.712 (1969); Va. Code ANN. § 19.1 (1950); W. VA. Code ANn. § 15-2-29(d) (Supp. 1970); Wis. Stat. ANN. $\S 165.83$ (Supp. 1971).

69 See, e.g., ILL. Rev. Stat. ANN. ch. 38, § 206-3 (Supp. 1970) (information furnished to "peace officers"); $c f$. WASH. REv. CODE ANN. \$ 72.50.140 (Supp. 1970), which is unique in that it allows a cause of action to one whose record is released in violation of the statute, with recovery of damages-including injury to reputation-caused thereby. The major failure of other statutes which attempt to provide for confidentiality is their total lack of enforcement provisions.

70 Kolb v. O'Connor, 14 Ill. App. 2d 81, 142 N.E.2d 818 (1957); Poyer v. Boustead, 3 IIl. App. 2d 562, 122 N.E.2d 838 (1954); State ex rel. Reed v. Harris, 348 Mo. 426, 153 S.W.2d 834 (1941); Hansson v. Harris, 252 S.W.2d 600 (Tex. Civ. App. 1952); see Marby v. Kettering, 89 Ark. 551, 117 S.W. 746, aff'd, 92 Ark. 81, 122 S.W. 115 (1909); People ex rel. Joyce v. York, 27 Misc. 658, 59 N.Y.S. 418 (Sup. Ct. 1899); cf. State ex rel. Burns v. Clausmeier, 154 Ind. 599, 57 N.E. 541 (1900). See also McGovern v. Van Riper, 140 N.J. Eq. 341, 54 A.2d 469 (Ch. 1947); Hodgeman v. Olsen, 86 Wash. 615, 150 P. 1122 (1915).

71 Cf. Scott v. County of Nassau, 23 Misc. 2d 648, 252 N.Y.S.2d 135 (Sup. Ct. 1964).

72 See, e.g., Moore v. Board of Chosen Freeholders, 76 N.J. Super. 396, 184 A.2d 748, modified, 39 N.J. 26, 186 A.2d 676 (1962).

73 See note 11 supra.

74 See, e.g., Holcombe v. State ex rel. Chandler, 240 Ala. 590, 200 So. 739 (1941). 
either arrest records should be made public or both access and dissemination should be restricted. ${ }^{75}$

\section{B. Limiting Dissemination}

1. The Competing Interests. In deciding whether arrest records should be made public, several factors become relevant. The individual with an arrest record, of course, has strong interests in limiting dissemination. First, unrestricted dissemination is likely to damage his reputation seriously. In some cases the record is either incomplete as to disposition or inaccurate, ${ }^{76}$ thereby increasing the probability that it will be misinterpreted as evidencing guilt. Even if the record is complete, the reader will often infer that the individual is in some way a "criminal." Second, the consequences of such dissemination can be economically disastrous. Licensing boards at all levels usually obtain copies of the record and consider them in deciding whether to deny or revoke a license. ${ }^{77}$ The arrested individual faces difficulties in obtaining insurance, credit, education, and even entry into the armed services. ${ }^{78}$ Most important, governmental agencies and private groups with access to records frequently use them to refuse the individual employment. ${ }^{79}$ Finally, and independent of these harms, unrestricted dis-

75 Presently an individual does not have access to his own arrest record. In view of the discussion above concerning limited public access, however, there seems to be no good reason for this practice. See, e.g., Scott v. County of Nassau, 23 Misc. 2d 648, 252 N.Y.S.2d 135 (Sup. Ct. 1964). Even if public access were limited, it would seem essential that the individual and his attorney have unrestricted access to his record for the purpose of checking accuracy, especially in light of recent federal legislation concerning an individual's access to his own credit files. But see text at note 93 infra.

76 See Miller, supra note 12, at 34, noting that court proceedings following an arrest are not furnished for about $35 \%$ of the "rap sheets" in FBI files. See also InTERNational Ass'n of Chiefs of Police, A Survey of the Police Department, Chicago, Illinois 824 (1970), noting that many case reports in the Chicago files were inaccurate or misclassified.

77 DunCan RePorr, supra note 12, at 14-15.

78 See, e.g., Gough, supra note 11, at 153-57.

79 For evidence of this practice and a discussion of the consequences for the individual, sce Duncan Report, supra note 12, at 9-15; Hess \& LePoole, Abuse of the Record of Arrest Not Leading to Conviction, 13 CRIME \& DELINQ. 494, 498 (1967). One study indicates that approximately $75 \%$ of the New York City area employment agencies sampled do not refer an applicant with a record, regardless of whether the arrest was followed by a conviction. E. Sparer, Employability and the Juvenile "Arrest" Record (unpublished study by the New York University Center for the Study of Unemployed Youth, 1966). In another study, two-thirds of the employers surveyed would not consider employing a man acquitted of assault charges. Schwartz \& Skolnick, Two Studies of Legal Stigma, 10 Social Prob. 133, 136 (1962). These economic consequences are likely to weigh heaviest on those who can least bear the burden-the poor and the black. DUNCAN REPORT, supra note 12 , at 7 . Moreover, a person may be arrested for a variety of reasons. In Menard, Judge Bazelon noted that many people are arrested for "investigation," or en masse, or for harassment purposes with no hope of ultimate conviction. 430 F.2d at 493-94. Police administrators have even admitted that three out of four arrests are probably illegal. Hess \& LePoole, supra, at 495-96. 
semination of the arrest record disregards the individual's psychological interest in preventing disclosure of "personal information" without his consent. ${ }^{80}$ The concepts of intimacy, identity, role-playing, and autonomy all involve the notion that the individual ought to have some control over what others know about him. ${ }^{81}$

Militating against the individual's interests are those of police and the public. First, both police and the public have an interest in dissemination to persons outside the criminal justice system who may help police prevent crime and apprehend criminals. Second, the public has an interest in unlimited access in order to minimize business risks by basing decisions on full disclosure of facts concerning an individual. ${ }^{82}$

Since the common law rationale for use of arrest records is premised on law enforcement purposes, "business risk" interests should not be determinative unless they are relevant to law enforcement. Furthermore, it is doubtful whether the general public is capable of utilizing arrest records in an intelligent manner to minimize the incidence of crime. More probably, the presence of an arrest record becomes a convenient excuse for denying employment. Even if no inference of guilt is drawn, ${ }^{83}$ a businessman may still refuse employment ${ }^{84}$ on the basis of a high probability of rearrest, ${ }^{85}$ an event that would cost the employer time and money. This rationale may, however, become a self-fulfilling prophecy: denial of employment because of the

80 Since the person is no longer cast in the public eye, the arrest record might be considered "personal information" in relation to certain people. See text at notes 108-10 infra.

81 Project-Computerization of Government Files-What Impact on the Individual? 15 U.C.L.A.L. REv. 1371, 1411-1422 (1968).

82 Karst, supra note 12, at 366 , suggests that all arrest and criminal records be made public to end the "corroding, demoralizing occupation of information peddling within police departments," and that emphasis be placed on legislative proposals restricting certain uses of this data. Indeed, this alternative may be more consistent with the "free flow of information." However, any prohibition on use would have the same problems regarding proof and control as those regarding limitation of dissemination, and there is evidence that making arrest records public would invite disaster for those with records if no legislative guidelines were established. For example, in the District of Columbia in 1963 a new policy of almost total public dissemination resulted in a total of more than 3,500 records disseminated a week. DUNCAN REPORT, supra note 12, at 15 . The overwhelming effects of this practice have already been noted. See note 79 infra. If these practices are to be curtailed, controls on both dissemination and use seem necessary. See also text at notes 127-29 infra.

83 As Judge Bazelon noted in Menard, "Even if we assume that the cryptic reference on appellant's fingerprint card to release 'in accordance with $849(\mathrm{~b})(1)$ ' would be understood by police, it is questionable whether it would be understood by potential employers or the general public." $430 \mathrm{~F} .2 \mathrm{~d}$ at 492.98 .

84 See President's Comm'n on LAw Enforcentent \& Administration of Justice, supra note 5 , at 75-76 (1967).

85 An FBI study showed that $92 \%$ of those arrested but acquitted or dismissed in 1963 had been rearrested by 1969. Fenderal Bureau of INYEstigation, U.S. DeP'T OF Justice, supra note 5 , at $\mathbf{3 8 .}$ 
possibility of rearrest can itself become a cause of rearrest. ${ }^{86}$ In this context the individual's interests, because they are more direct and substantial, should prevail over the interests of the business enterprise.

There are, of course, some instances in which dissemination outside the criminal justice system promotes crime prevention. For example, a school board may use an arrest record to deny a job as a school bus driver to a man repeatedly arrested for drunk driving and child molesting. Selective distribution to such agencies as railroad police or state licencing boards certainly has greater crime prevention possibilities than distribution to a credit bureau or private employer. Yet it should be noted that persons outside the criminal justice system have no particular responsibility to use records for law enforcement purposes. Their objectives may be unrelated to the police function, and they can use arrest records for a variety of purposes, a power that carries with it strong possibility of abuse. Additionally, private individuals or groups can freely distribute the record once it is given out. While theoretically the question whether to disseminate can be decided fairly by weighing the probability of crime prevention in each case against that of potential harm to the individual, the exercise of unfettered discretion by police has so far produced rather unsatisfactory results. The present widespread dissemination of arrest records seems to indicate that the interests of the individual are either discounted or disregarded entirely.

2. A Standard for Limiting Dissemination. Recently, in Morrow v. District of Columbia, ${ }^{87}$ the Court of Appeals for the District of Columbia Circuit in an opinion by Judge Wright evaluated some of these considerations. The case sustained the power of the District of Columbia Court of General Sessions to assume ancillary jurisdiction after dismissal of a criminal case and to issue an order prohibiting dissemination of the defendant's record. Reversing and remanding for a decision on the proper scope of restriction on dissemination, the court incorporated the Duncan Report ${ }^{88}$ in an appendix to its opinion. ${ }^{89}$ The Report, eventually enacted by the District of Columbia, recommended that dissemination of arrest records where there had been no conviction or

86 There is reason to believe that the probability of rearrest is a function of unemployment and that existing rearrest probability figures are based on a high unemployment population sample. For example, one group noted that in a "special study made for the President's Commission on Crime in the District of Columbia, it appeared that over 50 percent of the offenders studied were unemployed at the time of the crime." National Capitol Area Civil Liberties Union, The Maintenance and Use of Arrest Records (unpublished report, 1967).

87417 F.2d 728 (D.C. Cir. 1969).

88 Supra note 12.

89417 F.2d at 745 . 
forfeiture of collateral be limited to "law enforcement agents" for "law enforcement purposes." ${ }^{90}$ On remand, the District of Columbia Court of Appeals decided that the rules established by the Duncan Report were sufficient to protect the record in question. ${ }^{91}$

This "insider-outsider" standard seems to be the most appropriate one for restricting access and dissemination in a manner consistent with the policy previously discussed-it protects the individual while serving the necessary law enforcement purposes. Since there is latitude in determining what are law enforcement agencies and purposes, the rule is sufficiently flexible. Such organizations as licensing boards might obtain records if they specified reasons and subjected themselves to rules insuring complete confidentiality. ${ }^{92}$ The Duncan Report standard is also important because it allows access to defense attorneys, who under present practice frequently obtain records only at the prosecutor's discretion. ${ }^{93}$ Furthermore, it would seem essential to allow the arrested individual access to his own record in order to insure its completeness and accuracy. However, because employers often require police clearance as a condition of employment, such a provision may allow the employer to circumvent normal prohibitions unless measures are taken to protect the individual from pressure to produce the record. Additionally, if the record is disseminated to anyone other than law enforcement agents, notification should be given to the individual affected; at least then he would be in a position to challenge the decision if he so desired.94

\section{Limiting Dissemination: Individual Rights and Remedies}

1. Rights. Several legal theories are available to a person seeking to enjoin, or to obtain damages for, the dissemination of his arrest record to "outsiders." The first arises from the law of privacy and is

90 DUNCAN REPORT, supra note 12, at 23-27.

91 In re Alexander, 259 A.2d 592 (D.C. Ct. App. 1969).

82 This practice might take care of examples such as that of the school bus driver since many jobs of public trust nature must be licensed. However, it might also invite abuse by licensing boards. Inequities would be decreased if the law stringently required, according to the equal protection clause, a reasonable connection with the arrest and the denial of the license. Compare cases cited note 129 infra with Pincourt v. Palmer, 190 F.2d 390 (3rd Cir. 1951); Camp v. Brock, 75 Cal. App. 2d 169, 170 P.2d 702 (1946); Hora v. City \& County of San Francisco, 43 Cal. Rptr. 527 (Dist. Ct. App. 1965). But see Menard v. Mitchell, 39 U.S.L.W. 2725 (D.D.C. June 15, 1971) (dissemination to licensing agencies prohibited).

93 Additionally, records should be available to independent study groups if precautions are taken to insure confidentiality or anonymity. Greater flexibility in administering the standard might be insured if records were also available by court order.

94 Morrow also notes that in addition to the Duncan Report standard arrest records in unusual cases may be returned. 417 F.2d at 741 . The above discussion of retention may provide a guide to these cases. 
exemplified by a case in which a court restrained the display of an arrested person's photograph in a public "rogues' gallery" after charges had been dismissed. ${ }^{95}$ The publication of an "innocent complaintant's photograph in juxtaposition with hardened criminals" placed the plaintiff in a "false light" in the public eye. ${ }^{96}$ Since the "false light" privacy theory is an outgrowth of the law of defamation, it is not surprising to find libel principles arising in cases of publication of arrest facts and records. For example, publication in a public "rogues' gallery" of a photograph of a person who had not been arrested has been held libel per se. ${ }^{97}$ If the fact of arrest is true, of course, publication thereof is not libelous. ${ }^{98}$ Nevertheless, in an analogous context, newspaper publication of a true fact of arrest with additional information which unambiguously conveys to the reader an imputation that the arrested individual is guilty of a crime has been held libelous as a matter of law.99 Where the article is capable of two interpretations, only one of which is libelous, the defamation issue has been held to be a question for the jury. ${ }^{100}$

These defamation or "false light" privacy cases suggest that at least two elements must be satisfied to constitute a cause of action: ( 1 ) the information released must have at least one libelous interpretation, and

95 State ex rel. Mavity v. Tyndall, 224 Ind. 364, 66 N.E.2d 755, cert. denied, 333 U.S. 834, rehearing denied, 333 U.S. 858 (1946); cf. Schulman v. Whitaker, 115 La. 628, 39 So. 737 (1905); Itzkovitch v. Whitaker, 115 La. 479, 39 So. 499 (1905); Downs v. Swann, 111 Md. 53 (1909) (dictum). See also State ex rel. Reed v. Harris, 348 Mo. 426, 153 S.W.2d 834 (1949).

96 State ex rel. Mavity v. Tyndall, 224 Ind. 364, 381, 66 N.E.2d 755, 762, cert. denied, 333 U.S. 834, rehearing denied, 333 U.S. 858 (1946).

97 Wisher v. City of Centralia, 273 Ill. App. 168 (1933).

98 Compare Rein v. Sun Printing \& Publishing Co., 196 App. Div. 873, 188 N.Y.S. 608 (1921), with Brewer v. Chase, 121 Mich. 526, 80 N.W. 575 (1899) (false publication charging guilt); Martin v. Orange County Publications, Inc., 49 Misc. 2d 84, 266 N.Y.S.2d 875 (Sup. Ct.), aff'd, 25 App. Div. 2d 471, 266 N.Y.S.2d 348 (1965) (false publication charging arrest). See also Bennett v. Norban, 396 Pa. 94, 151 A.2d 476 (1959); Hanson v. Krehbiel, 68 Kan. 670, 75 P. 1041 (1904).

99 Smith v. New Yorker Staats Zeitung, 154 App. Div. 458, 139 N.Y.S. 325 (1913); Lancour v. Herald \& Globe Ass'n, 111 Vt. 371, 17 A.2d 253 (1941).

100 Commercial Publishing Co. v. Smith, 149 F. 704 (6th Cir. 1907); cf. Hawley v. Professional Credit Bureau, 345 Mich. 500, 76 N.W.2d 835 (1966); Steward v. World-Wide Automobiles Corp., 20 Misc. 2d 188, 189 N.Y.S.2d 540 (Sup. Ct. 1959). See also Watkins v. United States, 354 U.S. 178 (1957) (congressional committee lumping "innocent" with "guilty").

Although a privilege is extended to the reporting of official judicial proceedings involving arrest facts, it is a qualified privilege which may be lost if additional facts are added. Smith v. New Yorker Staats Zeitung, 154 App. Div. 458, 139 N.Y.S. 325 (1913). Also, a report based on an arrest record is not based on a "public record" and should not be subject to the public record privilege. See text at notes 82-84 supra. Furthermore, if the publication imputes guilt it is not privileged even if based on a police report. Lancour v. Herald \& Globe Ass'n, 111 Vt. 371, 17 A.2d 253 (1941). 
(2) it must be published or made available to the general public. The former element is easily satisfied where the arrest record is comprised largely of cryptic notations, or phrased in terminology which would be of doubtful intelligibility to persons outside the criminal justice system. ${ }^{101}$ In this context, the reader would probably infer guilt rather than merely the true fact of arrest. Moreover, if the record is incomplete - for example, if the disposition is lacking-the likelihood that a reasonable man would infer guilt may be so great that dissemination could be restrained. ${ }^{102}$

There may, however, be crippling limitations on use of defamation and privacy theory. ${ }^{103}$ Dissemination to a restricted audience may not be sufficient to qualify as the "publication" required by traditional privacy doctrine. Furthermore, the courts have declined to entertain plaintiff suits because of a reluctance to limit police discretion. ${ }^{104}$ Particularly striking are cases in which courts have refused to sustain invasion of privacy claims where records were made available to employers ${ }^{105}$ and where arrest photographs were displayed to a large public audience at a junior high school after charges had been dismissed.108

However, a Maryland case, Carr $v$. Watkins, ${ }^{107}$ presents a privacy concept which may require limitation on dissemination of arrest records regardless of their defamatory character. While the plaintiff was working for a naval ordnance laboratory, non-criminal charges were made concerning the suitability of his continued employment, but he was exonerated after an administrative hearing. Six years later a laboratory security officer and two police officers transmitted this information, including particulars of the charges, to the plaintiff's new employer, realizing that the consequence would be his discharge from employment. The court sustained a cause of action for invasion of privacy, holding that the officers had unreasonably and seriously interfered with the plaintiff's interest in not having his affairs disclosed to others. Other cases similarly recognize this right, requiring only that the subject be a

101 See note 83 supra.

102 If a plaintiff knew his arrest record was inaccurate or incomplete, he might use these tort theories in conjunction with the analysis at note 43 supra at least to require completion.

103 For a discussion of possible constitutional limitations on these rights, see note 118 infra.

101 See cases cited note 70 supra. These cases may not be controlling, however, because usually there had been no allegation or showing that the arrest photographs or records would be disseminated to parties other than law enforcement agencies.

105 Norman v. City of Las Vegas, 64 Nev. 38, 177 P.2d 442 (1947).

106 Hoag v. Superior Court, 24 Cal. Rptr. 659 (Dist. Ct. App. 1962).

107177 A.2d 841 (Md. Ct. App. 1962). 
"private affair" and that the disclosure be "public" and offend a person of ordinary sensibilities. ${ }^{108}$

In the context of dissemination of arrest records, a record might be considered a "private affair." Disclosure of the record to "outsiders" would constitute an unreasonable interference with a plaintiff's right not to have his affairs disclosed and would seem to offend a person of ordinary sensibilities. Although there may not be "public" disclosure, the breach of a confidential relationship might be sufficient to warrant redress. ${ }^{109}$ This type of tortious conduct has been recognized in similar situations. ${ }^{110}$

Finally, even if the privacy rationale is not expanded to reach dissemination cases, a person with an arrest record might be able to invoke the equity powers of a court ${ }^{111}$ to limit dissemination because he may be harmed without any direct countervailing social gain. ${ }^{112}$ This is precisely what occurred in Morrow. ${ }^{113}$

2. Remedies. An arrested individual might be able to prevent improper dissemination to "outsiders" by injunctive relief on one of several grounds. He could request such relief under the "unauthorized

108 See Prosser, supra note 48, at 392-98; Melvin v. Reid, 112 Cal. App. 285, 297 P. 91 (1931); Sidis v. F-R Publishing Corp., 113 F.2d 806 (2d Cir. 1940).

109 Redress is often provided against one who breaches a confidential relationship and divulges privileged communications. Lawyers, physicians, bankers, employers, spouses, and others have been held liable. J. Sharp, Credrr Reporting and Privacy 62 (1970). See, e.g., Munzer v. Blaisdell, 183 Misc. 773, 49 N.Y.S.2d 915 (Sup. Ct. 1944), aff'd, 269 App. Div. 970, 58 N.Y.S.2d 300 (1945); Brex v. Smith, 104 N.J. Eq. 386, 146 A.34 (Ch. 1929). The difference between the relationship in these cases and the "confidential relationship" between an arrested person and police is that arrest facts are public at the time of arrest. They do not become confidential until they become part of the arrest record. However, if the record is truly confidential, there should be a similar duty imposed on an "insider" not to divulge information to persons outside the confidential relationship. But see Hawley v. Professional Credit Bureau, 345 Mich. 500, 76 N.W.2d 835 (1956). Moreover, this invasion of privacy theory is closely related to the "intrusion" line of privacy cases. Dissemination to or use by persons not justified in having access may be a new intrusion into what should be considered "private affairs." See Prosser, id. at 396.

110 See Annot., 165 A.L.R. 1302, 1304-05 (1946).

111 See notes 53-55 supra.

112 Recent developments indicate that a person with an arrest record might have a constitutional right to have dissemination limited. In a recent case, Wisconsin v. Constantineau, 91 S. Ct. 507 (1971), the Supreme Court held that a Wisconsin statute which allowed the posting of notices in liquor stores declaring plaintiff to be an "excessive drinker" and forbidding the sale of alcohol to her without prior notification or hearing was unconstitutional on its face as a denial of due process. For the majority, Justice Douglas wrote: "Yet certainly where the state attaches a 'badge of infamy" to the citizen, due process comes into play. ... Where a person's good name, reputation, honor or integrity are at stake because of what the government is doing to him, notice and an opportunity to be heard are essential." Id. at 510. Dissemination of arrest records beyond law enforcement agencies without notice to the individual does not seem much different.

113 See text at note 87 supra. 
disclosure" privacy rationale of $\mathrm{Carr}^{114}$ or invoke general equitable relief at the conclusion of his criminal trial, as in Morrow, ${ }^{115}$ or in a new civil proceeding. The injury resulting from the threat of dissemination would probably be sufficient to confer standing. ${ }^{116}$ Presumably a decree would be designed to prevent transmission of the record to non-law enforcement organizations outside the jurisdiction entertaining the suit. Injunctive relief would, of course, permit use of the contempt power to insure official cooperation. ${ }^{117}$

Where improper dissemination has already occurred, a suit for damages based on a privacy or libel theory might succeed if the record were misleading. Even if the record were clear, the Carr rationale suggests a basis for compensation. The possibility of damage recovery against "insiders" is an important general deterrent to police misconduct in this area and would protect those who were too poor to sue, who could not prove violations, or who would fail to sue because of potentially insufficient damages. ${ }^{118}$

Aside from these difficulties, however, a plaintiff might be prevented from suing for damages by the privilege doctrine, which often bars suits for misconduct by public officials. ${ }^{119}$ This doctrine is designed to insulate public officials from attack so that they may continue in the "unflinching discharge of their duties."120 The privilege is often held

114 See text at notes 107-110 supra.

115 But see Maxwell v. O'Connor, 1 Ill. App. 2d 124, 117 N.E.2d 326 (1953). Aside from Morrow, the controversy over a criminal court's power to limit dissemination or require return of an arrest record of the person before the court continues. See United States v. Penny, Civil No. 34-7270 (D.D.C., filed Nov. 25, 1970).

116 For a more detailed discussion of standing, see note 53 supra.

117 Hearings on compliance with the order are an alternative, but so far they have met with difficulties. In MIorrow, the court held the burden to be on the defendant to show noncompliance before a hearing will be ordered. $417 \mathrm{~F} .2 \mathrm{~d}$ at 744 .

118 For a discussion of the general limitations of a damage suit as a means of controlling access and dissemination of files, see Karst, supra note 12, at 350-52. The author notes that the first amendment privilege may be a constant factor to contend with in any suit for injunction or damages based on the right to privacy. One requirement for the privilege is that the matter be of "public interest." Current arrest facts, of course, are of public interest. Arrest records, excluding present arrest facts, on the other hand, should be less a matter of public interest for the reasons discussed in the text at notes 82-86 supra. But arrest records of such persons as public officials, who are cast into the public eye, may warrant separate consideration. See Time v. Pape, 91 S. Ct. 633 (1971); New York Times v. Sullivan, 376 U.S. 254 (1964).

110 In Barr v. Matteo, 360 U.S. 564 (1959), the Supreme Court held that the acting director of the federal office of rent stabilization was absolutely privileged in a libel action and that the privilege extended to kindred torts.

120 Gregorie v. Biddle, 177 F.2d 579, 581 (2d Cir. 1949). One reason for the privilege is related to the doctrine of sovereign immunity and the policy of holding individual officers not liable for actions taken pursuant to their perceived duties. Enactment of indemnity statutes or abolition of the doctrine, which would permit holding liable the government instead of its officers, might change the nature of the privilege. Recovery 
to be absolute, even where officers have acted willfully and with malice. ${ }^{121}$ Nevertheless, some cases recognize a qualified privilege and hold certain public officers liable where they have acted outside the scope of their authority. ${ }^{122}$ Dissemination to "outsiders" by an officer in willful violation of a clear standard would likely be outside the scope of his authority and there, at least, the privilege doctrine would not bar a damage action.

It is therefore of primary importance that a standard governing dissemination be uniform and clearly defined. Otherwise, little protection can be offered the injured plaintiff in most cases. ${ }^{123}$ Moreover, compliance with injunctive orders would certainly be facilitated by a standard which could be applied by law enforcement agencies without unnecessary confusion.

The applicable standard could be formulated in a number of ways. A court could adopt its own principle ${ }^{124}$ or request a defendant law enforcement agency to submit a proposal for judicial approval. Alternatively, a class action would allow a court to adjudicate the rights of all persons with arrest records in a given jurisdiction. Of course, greater uniformity would be achieved by adoption of a comprehensive legislative solution or viable administrative rules.

Certainly, the ultimate goal is uniform compliance. In the age of instant photocopy and national computer data banks, the freedom of a single party to breach an established standard with impunity could render imposition of dissemination controls valueless. The creation of nationwide guidelines limiting dissemination and concomitant establishment of remedies to enforce those guidelines would go far to effectuate uniform compliance.

\section{Limitations of This Approach}

The benefit of limiting dissemination to "insiders" is that no decision could be made by "outsiders" on the basis of the arrest record without

might then be had against the government for damages caused by dissemination to outsiders, creating economic pressure to enforce the standard.

121 See 3 K.C. Davis, supra note 53, at $\$ 26.05$.

122 See, e.g., Carr v. Watkins, 177 A.2d 841 (Md. Ct. App. 1962).

123 If the standard is breached because of outside monetary persuasions, bribery laws should be available as a similar deterrent. See N.X. Times, Feb. 4, 1971, at 60, reporting that a New York City patrolman was indicted for accepting money in exchange for confidential information from police files. Of course, whenever a standard is breached, there are two guilty parties-the seller and the buyer-and it may be unfair to place all the burden of honesty on one side. But see text at note 126 infra.

124 In Morrow, the court declared that on remand the District of Columbia Court of Appeals had full power to adopt an individual case approach, the Duncan Report standard, or its own standard, indicating that a court has full power to articulate a standard in any case before it. 
first confronting the individual. Unfavorable credit ratings, difficulty in obtaining insurance, and employment rejections based on data bank information not supplied by the individual would decrease. However, even if a uniform standard were adopted and enforced, restricting dissemination would not completely eliminate "outsider" use. Employment questionnaires regularly ask whether a prospective employee has been arrested, and there is great pressure on the individual to reveal everything. ${ }^{125}$ On the other hand, since the employer would not have the official record for verification, the prospective employee could falsify with impunity. Some leakage would, of course, seem to be inevitable. If the harm resulting from retention of arrest records is great compared with their usefulness, expungement remedies may warrant reconsideration; return of arrest records may after all be necessary.

An emerging problem to be confronted is that present judicial response is aimed only at record keeping within the criminal justice system. Such organizations as newspapers, which have legitimate access to initial facts of arrest, can organize this information according to name, in effect duplicate arrest records, and open the door to circumvention of limits on dissemination. ${ }^{128}$ Expansion of the privacy theory of unreasonable intrusion into private affairs and the ability to sue "outsiders" might be sufficient to curtail such practices, but direct limitations on use of arrest records appear necessary to eliminate them completely.

One court has created a direct limitation on use by enjoining a company from denying a job to a black man on the basis of numerous arrests. The court held that since blacks are arrested more often than whites, such a practice results in racial discrimination under Title VII of the Civil Rights Act of 1964.127 A real problem in such situations is proving use, but this case suggests that the difficulty is not insurmountable. However, the ruling may be limited in effect since presumably the company could still deny employment to whites on this basis. The federal government as an employer has made some attempt to reduce

125 There have been legislative attempts to prohibit employers from asking whether prospective employees have been arrested, but so far they have met with failure. See Hess \&: LePoole, supra note 79, at 499.

126 In fact, this practice may to some extent already exist. See the reference to "clipping agencies" in Note, supra note 50, at 477 (1971).

127 Gregory v. Litton Systems, Inc., 316 F. Supp. 401 (C.D. Cal. 1970). See generally Comment, Arrest Records as a Racially Discriminating Employment Criterion, 6 HARv. Civ. Rights-Crv. LIB. L. Rev. 165 (1971). The logic of this case, however, probably goes too far. Males are arrested more often than females; Title VII of the Civil Rights Act of 1964 also prohibits discrimination on the basis of sex; therefore, denying jobs to men on the basis of numerous arrests also results in prohibited sexual discrimination. Yet to deny employment to white females, the only group left, would probably be a denial of equal protection. 
its use of arrest records by eliminating questions concerning nonconviction arrests from employment questionnaires. ${ }^{128}$ Beyond that, the government may be under a constitutional duty not to use the fact of an arrest to deny employment or a license unless there is a reasonable connection between the privilege denied and the cause of the arrest. ${ }^{129}$ In order to regulate effectively the use of arrest records by both the government and private persons, more comprehensive legislation will probably be necessary.

\section{ConcLUSION}

As computerization augments police capacity to gather and store arrest records, an increasing number of people may obtain access to and use of such records. Adverse effects on arrested individuals will increase unless the law develops an effective means of regulating record keeping. Although comprehensive legislation would have certain advantages, there is both the need and sufficient common law authority for the development of judicial supervision in this area. Requiring return of arrest records proven not useful would help eliminate continued reliance on them. Limiting dissemination of unreturned records to "insiders" would not eliminate all use, but it would allow the individual with the arrest record to escape, in part, its stigma and place the legal system one step closer to a true presumption of innocence.

128 PRESIDENT'S COMm'N ON LAW ENFORCEMENT \& ADMinistration of Justice, supra note 5 , at 75 .

129 See, e.g., Mindel v. United States Civil Serv. Comm'n, 312 F. Supp. 485 (N.D. Cal. 1970) (termination of job as postal clerk because employee living with a woman and not married unconstitutional because no rational nexus with job); Norton v. Macy, 417 F.2d 1161 (D.C. Cir. 1969) (alleged homosexual advance by civil service employee toward another insufficient to justify dismissal). 